\title{
Sanky (Corryocactus brevistylus) Peel as Low-Cost Adsorbent for Removal of Phosphate from Aqueous Solutions
}

\author{
Eliana Contreras-López ${ }^{1}{ }^{\mathbb{D}}$, Victor Miyashiro Kiyan ${ }^{2} \mathbb{D}$, Jaime Porras Cerrón ${ }^{3}$, Ana María Muñoz ${ }^{4}$, \\ Fernando Ramos-Escudero ${ }^{4, *(\mathbb{D})}$, Marcelo Portuguez-Maurtua ${ }^{5}$ (D), Ricardo Yuli-Posadas ${ }^{6}$ and \\ Humberto Garayar-Tasayco ${ }^{7}$
}

check for updates

Citation: Contreras-López, E.; Miyashiro Kiyan, V.; Porras Cerrón, J.; Muñoz, A.M.; Ramos-Escudero, F.; Portuguez-Maurtua, M.;

Yuli-Posadas, R.; Garayar-Tasayco, H. Sanky (Corryocactus brevistylus) Peel as Low-Cost Adsorbent for Removal of Phosphate from Aqueous

Solutions. Sustainability 2021, 13, 8994 https://doi.org/10.3390/su13168994

Academic Editor: Danilo Spasiano

Received: 10 July 2021

Accepted: 2 August 2021

Published: 11 August 2021

Publisher's Note: MDPI stays neutral with regard to jurisdictional claims in published maps and institutional affiliations.

Copyright: (c) 2021 by the authors. Licensee MDPI, Basel, Switzerland. This article is an open access article distributed under the terms and conditions of the Creative Commons Attribution (CC BY) license (https:/ / creativecommons.org/licenses/by/ $4.0 /)$.
1 Grupo de Investigación Revalorización de Fuentes Naturales y Alimentos Funcionales-REVALF, Facultad de Farmacia y Bioquímica, Universidad Nacional Mayor de San Marcos, Jr. Puno 1002, Lima 15001, Peru; econtrerasl@unmsm.edu.pe

2 Departamento Académico de Ingeniería Ambiental, Facultad de Ciencias, Universidad Nacional Agraria La Molina, Av. La Molina, Lima 15024, Peru; vmk@lamolina.edu.pe

3 Facultad de Economía y Planificación, Universidad Nacional Agraria La Molina, Av. La Molina, Lima 15024, Peru; jaimepc@lamolina.edu.pe

4 Instituto de Ciencias de los Alimentos y Nutrición, Universidad San Ignacio de Loyola (ICAN-USIL), Campus Pachacamac, Sección B, Parcela 1, Fundo La Carolina, Pachacámac, Lima 15823, Peru; amunoz@usil.edu.pe

5 Facultad de Ingeniería Agrícola, Universidad Nacional Agraria La Molina, Av. La Molina, Lima 15024, Peru; mportuguez@lamolina.edu.pe

6 Facultad de Medicina, Universidad Nacional Mayor de San Marcos, Av. Grau 1075, Lima 15001, Peru; ryulip@unmsm.edu.pe

7 Instituto de Investigación de Ciencias Sociales, Universidad Nacional de Huancavelica, Av. Agricultura 319-321, Paturpampa, Huancavelica 09001, Peru; humberto.garayar@unh.edu.pe

* Correspondence: dramos@usil.edu.pe or diomedes.fernando@gmail.com

Abstract: This study aimed to evaluate the adsorption capacity of an adsorbent obtained using sanky peel for the removal of phosphate from aqueous solutions. The study was conducted in two stages: (1) adsorbent preparation considering yield, phosphate removal, adsorption capacity, and textural characteristics; (2) an assessment of the effectiveness of using sanky peel as an adsorbent for removing phosphates from aqueous solutions. Batch adsorption was studied in aqueous solutions containing phosphate and calcium ions with the selected adsorbent. Adsorption kinetics and equilibrium isotherms were studied using mathematical models. The adsorption kinetics followed the pseudo-second-order, Elovich, and Weber-Morris models, thus demonstrating that adsorption rates were not controlled by multiple processes. Adsorption equilibrium data fitted best with the Dubinin-Radushkevich model. Finally, a Fourier transform infrared spectroscopy analysis revealed the presence of brushite spectra bands after adsorption. The results of this study can help better understand the use of sanky peel as an adsorbent and good alternative for aqueous phosphate adsorption.

Keywords: sanky peel; adsorbent; phosphate; kinetics; isotherms

\section{Introduction}

In many developing countries, poor water quality negatively affects human health, reduces food production, and intensifies poverty owing to poor accessibility to water treatment equipment, especially in rural areas [1]. Modern high-yield agriculture uses phosphate as a nutrient for food production, thereby releasing high concentrations of phosphorus into soil and enriching phosphate in surface and ground water [2]. Phosphate contamination of water bodies has implications for the environmental balance and can cause eutrophication [3], which is characterized by an excessive growth of algae and the decomposition of organic matter, thus deteriorating water quality, and causing parasitic infections $[4,5]$. 
Adsorption is the most widely used method for aqueous phosphate removal because it is an environmentally safe, simple, fast to operate, and economically viable process [5]. Fruit peel can be used to prepare adsorbents for removing different contaminants owing to its large surface area, high adsorption capacity, microporosity, and ion exchange capacity [6,7]. Moreover, peel accumulation creates several problems in waste management: transport, disposal, pests, vector proliferation, bad odors, visual and landscape impacts, the emission of greenhouse gases, a negative impact on the environment, threat to sustainable development, repercussions on economic aspects, human health, and social well-being [8].

Corryocactus brevistylus (Schumann) Britton and Rose is an arboreal cactus with an edible fruit called sanky [9]. This cactus has two subspecies: (1) Corryocactus brevistylus subspecie brevistylus, which is mainly found in southern Peru and northern Chile, and (2) Corryocactus brevistylus subspecie puquiensis (Rauh and Backeberg) Ostolaza, geographically distributed in the Andean regions of southern Peru (Arequipa, Ayacucho, Ica, and Huancavelica) $[10,11]$. These subspecies, endemic to Peru [12], are classified as "vulnerable" in the Red List of Threatened Species of the International Union for Conservation of Nature (IUCN) [10]. Therefore, they are protected in the Cotahuasi Landscape Reserve, Alto Selva Alegre Regional Ecological Park (Arequipa) [9], and Pampa Galeras-Barbara D'Achille National Reserve (Lucanas, Ayacucho) [13].

These plants are scattered at an average density of 10 plants per hectare for a total estimated population of 117,080 plants. As sanky is a wild species, no production or yield records exist; however, properly conformed plants at the harvest age produce an average of $5-10 \mathrm{~kg}$ fruit per plant [14]. Therefore, sanky production yields may range from 585,400 to $1,170,800 \mathrm{~kg}$ per year. Based on these estimates, the town of Saisa can generate $175,620-351,240 \mathrm{~kg}$ of sanky peel mass per year. Sanky is already collected in several high Andean communities [15]. Moreover, as it is a protected species [10,12], other Andean regions in Peru have also encouraged its repopulation and propagation $[15,16]$. Therefore, the use of sanky peel will favor the sustainable development of several high Andean communities.

A sustainable utilization of resources to fulfill human needs is important for biodiversity conservation, especially for conserving species in a vulnerable state [17]. Areas with the highest production of sanky in Peru are Saisa (Ayacucho), Chivay, Chiguata and Yura (Arequipa), and Moquegua [18]. Communities settled in these high Andean areas often share several common characteristics: a lack of economic resources, geographic isolation, inadequate and insufficient access routes, poor health service coverage, contaminated water consumption, a lack of drainage systems, poor hygiene practices, adverse environmental conditions, water scarcity, and low-tech agricultural practices, among others. A comprehensive use of sanky presents an opportunity for generating income, protecting the environment, and undertaking influential activities in the sustainable development of rural communities.

Sanky peel contains compounds required by the food and pharmaceutical industries. Contreras-López and Salvá Ruiz [19] used it as an ingredient in llama meat burgers to improve flavor and texture. Rojas et al. [20] quantified the phenolic components of hydroalcoholic extracts in 15 ultrasound-assisted treatments and optimized extraction conditions. Contreras-López et al. [21] used ultrasound-assisted extracts of sanky peel to assess the stability of the sensory and microbiological quality of ground llama meat in refrigerated storage. Rodríguez et al. [22] obtained the lipid profile of apolar sanky peel extracts, concluding that sanky peels contain mainly palmitic and linoleic acids.

Some rural community residents living near harvesting areas use sanky peel to clean their hair [23]. Therefore, sanky peel utilization becomes a part of the proposed circular economy model in which waste can be transformed into resources; thus, the economy can be more sustainable and reduce its negative environmental impact by improving the management of resources and reducing pollution [24]. Within this context, using peels for adsorbent production provides several benefits: reducing waste accumulation as an environment protection method, generating economic development opportunities 
by repurposing waste, decreasing aqueous pollutant concentrations, and promoting the conservation of threatened species.

Furthermore, this is the first study on the production of an adsorbent using sanky peels. The present work assesses the efficiency of sanky peel adsorbents in removing phosphate from aqueous solutions. Sanky peel was extracted as pulp waste and used as a precursor to an adsorbent in three adsorbent-preparation treatments (S01, S02, and S03). The following characteristics were determined for each of these three treatments: yield, phosphate removal, adsorption capacity, cost, and textural properties. Based on these characteristics, the adsorbent that presented an ecological and environmently friendly process with significant potential as a phosphate adsorbent was selected. Further, batch adsorption experiments were performed using aqueous solutions with calcium ions and the adsorbent selected in the aforementioned step. Phosphate removal by the adsorbent was observed through the presence of calcium ions in the aqueous solution. Subsequently, a factorial experimental design was used as a statistical tool to assess how the adsorption conditions of the aqueous solution influenced its phosphate adsorption capabilities. Different isothermal equations revealed that, at equilibrium, adsorption occurred at micropores. Moreover, adsorption kinetics indicated that adsorption was controlled by chemisorption. The process used in this study is simple, cost-effective, and easy to transfer.

\section{Materials and Methods}

\subsection{Preparation of Adsorbents}

Sanky peel used in this work was collected from a rural community located in the natural sanky forests of the Saisa district in the province of Lucanas, Ayacucho, Peru. Figure 1 provides the location map of the Saisa district, whose geographical coordinates are $14^{\circ} 56^{\prime} 10^{\prime \prime} \mathrm{S}$ latitude and $74^{\circ} 24^{\prime} 51^{\prime \prime} \mathrm{W}$ longitude.

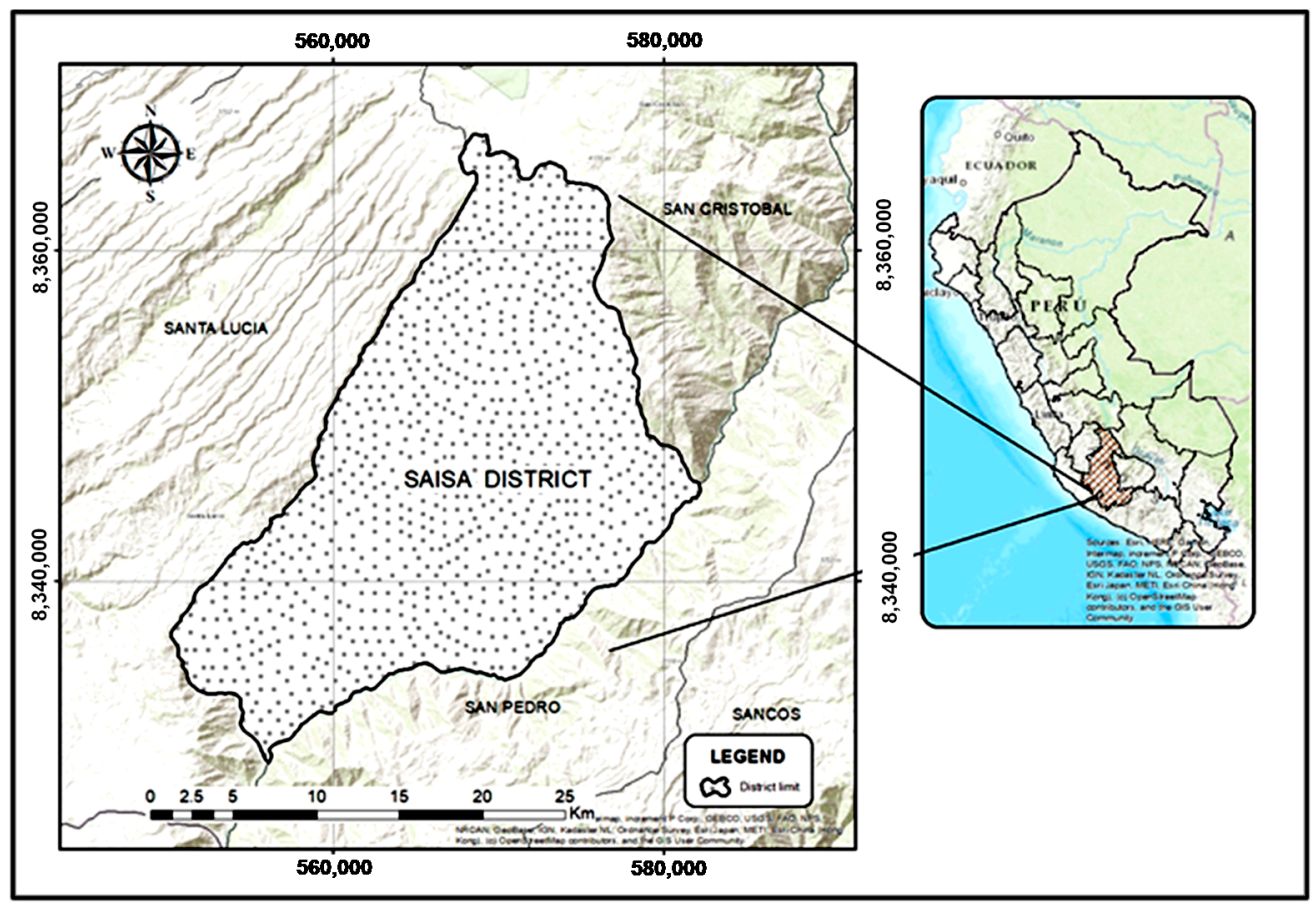

Figure 1. Geographical location of the Saisa district.

In the present study, the sanky peel was cut into four parts of approximately $3-4 \mathrm{~cm}$ each. Subsequently, each part was rinsed twice at $95{ }^{\circ} \mathrm{C}$ for $10 \mathrm{~min}$ with a peel-water ratio of 1:2. Further, the shell was dried in a Memmert UF55 oven at $50{ }^{\circ} \mathrm{C}$ for $48 \mathrm{~h}$. The dried peels were wrapped in aluminum and stored at $25^{\circ} \mathrm{C}$. 
Three adsorbent manufacturing treatments were tested. The first (S01) was obtained by reducing the size of the dry shell particles with a juicer (Oster). Particle classification was achieved using a No. 45 mesh (<355 microns). The second treatment (S02) was produced by charring samples from the first treatment (S01) in a muffle furnace (RELES $18 \times 18$ ) in the presence of oxygen at $500{ }^{\circ} \mathrm{C}$ for $2 \mathrm{~h}$. The last treatment (S03) was obtained following a methodology similar to that used by Yadav et al. [25]. Herein, the dried peel was washed twice with deionized water and immersed in $0.1 \mathrm{~N} \mathrm{NaOH}$ for $10 \mathrm{~min}$, followed by immersion in $0.1 \mathrm{~N} \mathrm{H}_{2} \mathrm{SO}_{4}$. The resulting mass was filtered and rinsed with deionized water, dried in shade at room temperature for $12 \mathrm{~h}$, and oven dried at $50{ }^{\circ} \mathrm{C}$ for $24 \mathrm{~h}$ until reaching a constant weight. The dried material was washed with an $80 \% \mathrm{H}_{2} \mathrm{SO}_{4}$ solution at an adsorbent-to-acid ratio of 1:1.5 by mass. Subsequently, the material was washed again with $\mathrm{NaHCO}_{3}$ and double-distilled water to remove any traces of acid. Further, it was dried in the oven for $24 \mathrm{~h}$ at $50{ }^{\circ} \mathrm{C}$ until reaching a constant weight. Finally, it was charred in a muffle furnace at $500{ }^{\circ} \mathrm{C}$ for $2 \mathrm{~h}$. The adsorbent was ground in a juicer. The size of the particles from the three treatments was classified using a No. 45 mesh.

\subsection{Adsorbate}

We prepared $50 \mathrm{mg} \mathrm{L}^{-1}$ of a standard phosphate solution by dissolving $219.5 \mathrm{mg}$ monobasic potassium phosphate, $\mathrm{KH}_{2} \mathrm{PO}_{4}$ (Merck KGaA) in $1000 \mathrm{~mL}$ double-distilled water. The stock solution was diluted to obtain the required initial phosphate concentration.

\subsection{Selection of Adsorbent}

A study assessing phosphate adsorption in aqueous solutions was conducted using the prepared three treatments (S01, S02, and S03). The adsorption dose was $50 \mathrm{mg}$ adsorbent per $25 \mathrm{~mL} \mathrm{KH} \mathrm{PO}_{4}$ aqueous solution with a $\mathrm{pH}$ level of 6.5 at room temperature. The phosphate solution was prepared at a concentration of $10 \mathrm{mg} \mathrm{L}{ }^{-1}$, sodium azide $\left(\mathrm{NaNO}_{3}\right.$, Merck KGaA purity $\geq 99 \%$ ) as a preservative at a concentration of $1 \mathrm{~g} \mathrm{~L}^{-1}$, and calcium chloride $\left(\mathrm{CaCl}_{2}\right.$, Merck $\mathrm{KGaA} \geq 98 \%$ purity) at a concentration of $1.11 \mathrm{~g} \mathrm{~L}^{-1}$ [2].

After a rest period, the solutions were centrifuged for $5 \mathrm{~min}$ at $4000 \mathrm{rpm}$, and the resulting supernatant was filtered with a filter paper. A stannous chloride method was used to determine the phosphate concentration. An ultraviolet-visible (UV-Vis) spectrophotometer (GENESIS 10S UV-Vis) was used at a wavelength of $690 \mathrm{~nm}$ [26].

The phosphate adsorption capacity $q_{t}\left(\mathrm{mg} \mathrm{g}^{-1}\right)$ was calculated using Equation (1) [27], and the phosphate removal efficiency was calculated through Equation (2).

$$
q_{t}=\frac{C_{0}-C_{t}}{m} \times V
$$

where $q_{t}\left(\mathrm{mg} \mathrm{g}^{-1}\right)$ represents the amount of adsorbate per adsorbent mass unit in time $t$; $C_{0}$ and $C_{t}\left(\mathrm{mg} \mathrm{L}^{-1}\right)$ denote the initial adsorbate concentration and adsorbate concentration after a period of time $t$, respectively; $V$ represents the volume of the solution (L); and $m$ denotes the adsorbent mass $(\mathrm{g})$.

$$
\text { Phosphate Removal }(\%)=\frac{C_{0}-C_{f}}{C_{0}} \times 100 \text {, }
$$

where $C_{0}$ and $C_{f}$ represent the initial and final phosphate concentrations $\left(\mathrm{mg} \mathrm{L} \mathrm{L}^{-1}\right)$, respectively.

The textural analysis of S01, S02, and S03 was performed through the BrunauerEmmett-Teller (BET) t-plot and Barrett-Joyner-Halenda (BJH) [28] methods using a surface area analyzer (Micromeritics Gemini VII 2390 V1.02, Atlanta, GA, USA). The samples were degassed at $250{ }^{\circ} \mathrm{C}$ for $2 \mathrm{~h}$ before adsorption. Nitrogen was used as the analysis gas (99\%) and liquid nitrogen at $-273.15^{\circ} \mathrm{C}$. 
The physical chemical characteristics of humidity, ash, and $\mathrm{pH}$ were determined according to the procedures described in the ASTM D2867-17 [29], ASTM D2866-11 [30], and ASTM D3838-05 [31] standards, respectively. Manufacturing costs were also evaluated.

\subsection{Physicochemical Characterization of the Selected Adsorbent}

The Boehm method [32] was used to determine the acidic and basic sites of the selected adsorbent. Point zero charge (PZC) was determined according to the methodology described by Faria et al. [33]. A Fourier transformed infrared spectroscopy (FTIR) was performed at room temperature using Thermo Scientific's FTIR Nicolet iS10 in the $4000-650 \mathrm{~cm}^{-1}$ range and a mid-infrared $\mathrm{KBr}$ beam scatterer.

\subsection{Batch Adsorption Studies}

A factorial experimental design was conducted for phosphate adsorption using the adsorbent selected in stage (1). Here, two factors were analyzed: $\mathrm{pH}(4.0,6.5$, and 9.0) and initial phosphate concentration $\left(1,2,5\right.$, and $\left.10 \mathrm{mg} \mathrm{L}^{-1}\right)$. The variables measured were phosphate removal efficiency and adsorption capacity. For each analysis set, a blank was employed as a reagent control, which was subjected to the same procedure.

\subsection{Adsorption Kinetics}

The initial adsorbent mass, solution volume, temperature, and phosphate concentration were set at $50 \mathrm{mg}, 25 \mathrm{~mL}, 299 \mathrm{~K}$, and $10 \mathrm{mg} \mathrm{L}^{-1}$, respectively. The adsorption of phosphate by the adsorbent was monitored at predetermined time intervals: 1, 6, 12, 24, 36, 48,72 , and $168 \mathrm{~h}$ until equilibrium was reached. Adsorption kinetic data were evaluated using four mathematical models.

The pseudo-first-order model linearized equation [34] is:

$$
\ln \left(q_{e}-q_{t}\right)=\ln q_{e}-k_{1} t
$$

where, $q_{\mathrm{e}}\left(\mathrm{mg} \mathrm{g}^{-1}\right)$ and $q_{\mathrm{t}}\left(\mathrm{mg} \mathrm{g}^{-1}\right)$ represent the phosphate adsorption capacity at equilibrium and at time $t(\mathrm{~h})$, respectively, and $k_{1}\left(\mathrm{~h}^{-1}\right)$ denotes the Lagergren or pseudo-first-order kinetic constant. The adsorption rate was calculated using the following equation [35]:

$$
\text { Adsorption Rate (pseudo - first order) }=k_{1}\left(q_{\mathrm{e}}-q_{\mathrm{t}}\right)
$$

The linearized pseudo-second-order equation [36] is:

$$
\frac{t}{q_{t}}=\frac{1}{k_{2} q_{e}^{2}}+\frac{t}{q_{e}},
$$

where, $q_{\mathrm{t}}\left(\mathrm{mg} \mathrm{g}^{-1}\right)$ and $q_{\mathrm{e}}\left(\mathrm{mg} \mathrm{g}^{-1}\right)$ represent the phosphate adsorption capacity at time $t$ (min) and at equilibrium, respectively, and $k_{2}\left(\mathrm{~g} \mathrm{mg}^{-1} \mathrm{~min}^{-1}\right)$ denotes the pseudosecond-order rate constant. The adsorption rate of the model was calculated using the following equation:

$$
\text { Adsorption Rate (pseudo - second order) }=k_{2}\left(q_{\mathrm{e}}-q_{\mathrm{t}}\right)^{2}
$$

In chemisorption processes, the Elovich model is applied generally [37]. The modeldescribing equation is [38]:

$$
\frac{d q_{t}}{d_{t}}=a e^{-b q_{t}}
$$

where $a\left(\mathrm{mg} \mathrm{g}^{-1} \mathrm{~min}^{-1}\right)$ represents the initial adsorption rate, and $b\left(\mathrm{mg} \mathrm{g}^{-1}\right)$ is related to the surface area covered and activation energy by chemisorption. 
Chien and Clayton [39] simplified the equation by assuming that the value of abt is considerably larger than one:

$$
q_{t}=\frac{1}{b} \ln (a b t)=\frac{1}{b} \ln (a b)+\frac{1}{b} \ln (t) .
$$

The Elovich rate was calculated using the following equation [38]:

$$
\text { Elovich Rate }=a e^{-b q_{t}}
$$

Weber and Morris (1963) developed a model to describe the intraparticle diffusion process. The intraparticle diffusion mechanism inside the pores of the adsorbent leads to the adsorbent featuring a homogeneous porous structure [37].

The equation that defines the intraparticle diffusion is given by:

$$
q_{t}=k_{\mathrm{W} \& \mathrm{M}} \cdot t^{0.5}+\mathrm{C},
$$

where $k_{\mathrm{W} \& \mathrm{M}}\left(\mathrm{mg}^{-1} \mathrm{~h}^{-1 / 2}\right)$ represents the intraparticle diffusion rate constant. Constant $C$ $\left(\mathrm{mg} \mathrm{g}^{-1}\right)$ refers to the thickness of the boundary layer.

\subsection{Adsorption Equilibrium Studies}

The adsorption studies were performed at different adsorbate initial concentrations: 1.0, 2.0, 5.0, and $10 \mathrm{mg} \mathrm{L}^{-1}$. The Langmuir, Freundlich, and Dubinin-Radushkevich isotherm models were selected to adjust the experimental data.

The Langmuir kinetic model linearized equation is [37]:

$$
\frac{C_{e}}{q_{e}}=\frac{1}{k_{L} q_{\max }}+\frac{C_{e}}{q_{\max }}
$$

where $C_{e}\left(\mathrm{mg} \mathrm{L}^{-1}\right)$ denotes the adsorbate concentration at equilibrium; $q_{e}\left(\mathrm{mg} \mathrm{g}^{-1}\right)$ represents the amount of adsorbate adsorbed at equilibrium; $k_{L}\left(\mathrm{~L} \mathrm{mg}^{-1}\right)$ represents the Langmuir adsorption constant; and $q_{\max }$ denotes the maximum adsorption capacity of the adsorbent.

The separation constant $R_{\mathrm{L}}$ or equilibrium parameter is another important property of the Langmuir adsorption isotherm used to characterize the degree of the occurred adsorption reaction [5]:

$$
R_{\mathrm{L}}=\frac{1}{\left(1+k_{L} C_{0}\right)}
$$

where $k_{L}$ represents the Langmuir constant, and $C_{0}$ denotes the initial concentration of sorbate in the solution. The separation factor, $R_{\mathrm{L}}$, indicates the shape of the isotherm or whether the adsorption is favorable according to the following criteria: if $R_{\mathrm{L}}>1$, it is unfavorable; if $R_{\mathrm{L}}=1$, it is lineal; if $0<R_{\mathrm{L}}<1$, it is favorable, and if $R_{\mathrm{L}}=0$, adsorption is irreversible [40].

The Freundlich model assumes that adsorption is caused by physisorption phenomena $[5,37]$. The linearized equation is:

$$
\log \left(q_{e}\right)=\log \left(k_{F}\right)+\frac{1}{n} \log \left(C_{e}\right),
$$

where $k_{F}$ represents the Freundlich's constant and $\frac{1}{n}$ adsorbent; $q_{e}$ denotes the amount of phosphate adsorbed at equilibrium $\left(\mathrm{mg} \mathrm{g}^{-1}\right)$; and $C_{e}$ represents the phosphate concentration at equilibrium.

The Dubinin-Radushkevich isothermal model was used successfully in solutions with intermediate concentrations [41]. This model assumes a multilayer character, which 
involves Van der Waal forces [42]. The linearized equation of the Dubinin-Radushkevich isotherm model is [43]:

$$
L n q_{e}=q_{\max }-\beta \varepsilon^{2},
$$

where $q_{e}\left(\mathrm{mg} \mathrm{g}^{-1}\right)$ represents the amount of adsorbate adsorbed per unit mass of the adsorbent at equilibrium; $q_{\max }\left(\mathrm{mg} \mathrm{g}^{-1}\right)$ denotes the maximum adsorption capacity; $\beta$ $\left(\mathrm{mol}^{2} \mathrm{~kJ}^{-2}\right)$ represents a constant related to the adsorption energy; and $\varepsilon\left(\mathrm{kJ} \mathrm{mol}^{-1}\right)$ denotes the potential adsorption [44].

The average free energy " $E$ " per adsorbate molecule can be calculated using the following relationship [41]:

$$
E=\left[\frac{1}{\sqrt{2 \beta}}\right],
$$

where $\beta$ denotes the constant of the isotherm.

\subsection{Statistical Analysis}

2.8.1. Selection of the Sanky Peel Adsorbent

The data obtained from the adsorbent material production yield (\%), phosphate removal efficiency (\%), and adsorption capacity $\left(\mathrm{mg} \mathrm{g}^{-1}\right.$ of $\mathrm{PO}_{4}{ }^{-3}$ ) variables were assessed using a completely randomized design (CRD) with three repetitions, whose linear additive model was:

$$
Y_{\mathrm{ij}}=\mu+\tau_{\mathrm{i}}+\varepsilon_{\mathrm{ij}}
$$

where $Y_{\mathrm{ij}}$ represents the variable response obtained when applying the $i$-th treatment (preparation process) in the $j$-th experimental unit (sanky peel); $\mu$ denotes the effect from the general mean; $\tau_{\mathrm{i}}$ represents the effect from the $i$ th treatment; and $\varepsilon_{\mathrm{ij}}$ denotes the experimental error obtained when applying the $i$-th treatment in the $j$-th experimental unit.

The analysis of variance was performed, and the Tukey test was used for the pairwise comparison tests.

\subsubsection{Batch Adsorption}

A batch phosphate adsorption test in an aqueous solution was performed using a $3 \mathrm{~A} \times 3 \mathrm{~B}$ factorial design in a CRD with three repetitions for each level combination of the factors under study. The factors assessed were three $\mathrm{pH}$ levels $(4.0,6.5$, and 9.0) and three phosphate concentrations $\left(1,5\right.$, and $\left.10 \mathrm{mg} \mathrm{L}^{-1}\right)$. The linear additive model at this stage was:

$$
Y_{\mathrm{ijk}}=\mu+\tau_{\mathrm{i}}+\beta_{\mathrm{j}}+\gamma_{\mathrm{ij}}+\varepsilon_{\mathrm{ijk}}
$$

where $\mu$ represents the effect from the general mean, and $\tau_{\mathrm{i}}$ represents the effects from Factor $1(\mathrm{pH}) i, i=1, \ldots$,I. $\beta_{\mathrm{j}}$ represents the effects from Factor 2 (initial phosphate concentration) $j, j=1, \ldots, \mathrm{J} \cdot \gamma_{\mathrm{ij}}$ denotes the interaction of Factors 1 and 2 at levels $i j . \varepsilon_{\mathrm{ijk}}$ represents the experimental error obtained when applying $\mathrm{pH}$ factor at level $i$ and the initial phosphate concentration factor at level $j$ in $k$-th experimental unit (selected adsorbent).

\section{Results and Discussion}

\subsection{Adsorbent Material}

The limitations of this study are related to the little information in the scientific documentation and the lack of prior research for the application of sanky peel as an adsorbent for aqueous pollutants removal and water treatment.

Adsorbent Characteristics. The prepared S01, S02, and S03 materials (Figure 2) were evaluated according to their characteristics, performance, manufacturing costs, phosphate removal efficiency, phosphate adsorption capacity, humidity, total ash content, and $\mathrm{pH}$ (Table 1), in addition to their textural parameters through nitrogen adsorption at $77 \mathrm{~K}$ (Table 2). 

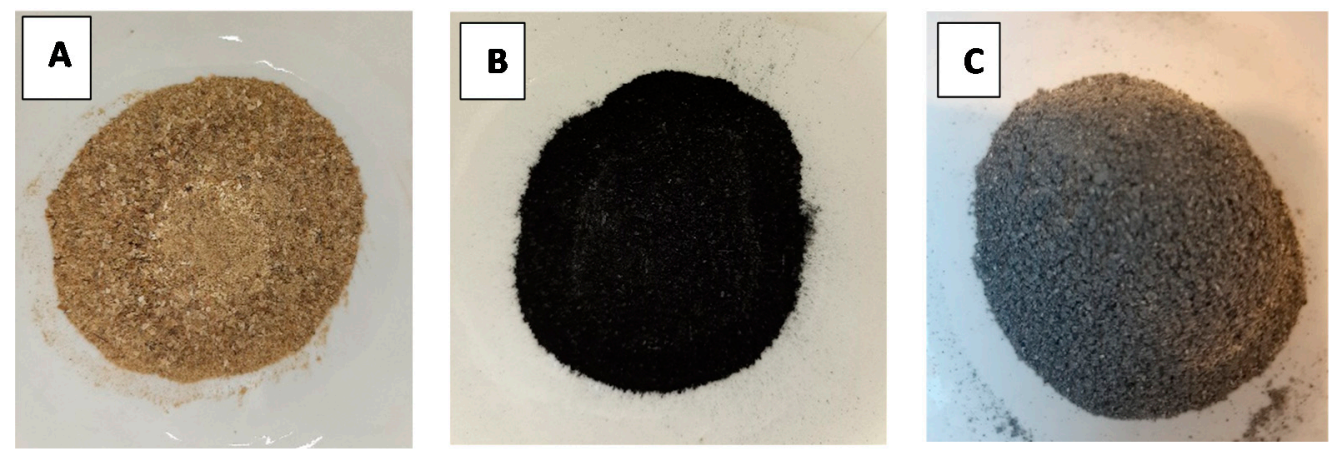

Figure 2. Materials obtained from the sanky peels. (A) S01, (B) S02 and (C) S03.

Table 1. Characteristics of the adsorbents obtained from the sanky peel.

\begin{tabular}{lccc}
\hline \multicolumn{1}{c}{ Parameter } & S01 & S02 & S03 \\
\hline Yield (\%) & $76.64 \pm 1.55$ & $28.01 \pm 1.55$ & $5.64 \pm 1.55$ \\
Cost (US\$/kg) & 2.49 & 13.04 & 45.72 \\
Phosphate removal efficiency (\%) & $-72.20 \pm 2.95$ & $61.10 \pm 2.95$ & $96.83 \pm 2.95$ \\
Phosphate adsorption capacity (mg/g) & $-18.05 \pm 0.39$ & $15.28 \pm 0.39$ & $24.21 \pm 0.39$ \\
Humidity (\%) & $10.61 \pm 0.81$ & $5.38 \pm 0.81$ & $4.61 \pm 0.81$ \\
Total ash (dry basis) (\%) & $16.55 \pm 1.86$ & $5.11 \pm 1.86$ & $4.64 \pm 1.86$ \\
$\mathrm{pH}$ (mass/volume $=1 / 20)$ & $3.34 \pm 0.03$ & $10.39 \pm 0.03$ & $10.26 \pm 0.03$ \\
\hline
\end{tabular}

Table 2. Textural analysis of the adsorbents derived from the sanky peel.

\begin{tabular}{|c|c|c|c|c|c|c|c|c|}
\hline Sample & $\begin{array}{c}S_{\text {BET }} \\
\left(\mathrm{m}^{2} / \mathrm{g}\right)\end{array}$ & $\begin{array}{c}S_{\mathrm{mi}} \\
\left(\mathrm{m}^{2} / \mathrm{g}\right)\end{array}$ & $\underset{(\%)}{S_{m i} / S_{\text {BET }}}$ & $\begin{array}{c}S_{\text {ext }} \\
\left(\mathrm{m}^{2} / \mathrm{g}\right)\end{array}$ & $\begin{array}{c}V_{\mathrm{mi}} \\
\left(\mathrm{cm}^{3} / \mathrm{g}\right)\end{array}$ & $\begin{array}{c}\text { VT } \\
\mathrm{cm}^{3} / \mathrm{g}\end{array}$ & $\begin{array}{c}\mathrm{V}_{\mathrm{mi}} / \mathrm{VT} \\
(\%)\end{array}$ & $\underset{(\mathrm{nm})}{\mathrm{D}_{\mathrm{p}}}$ \\
\hline S01 & -0.41 & - & - & - & - & - & - & - \\
\hline S02 & 9.32 & 4.97 & 53 & 4.36 & 0.0025 & 0.268 & 10 & 7.73 \\
\hline S03 & 14.92 & 3.27 & 22 & 11.65 & 0.0014 & 0.016 & 9 & 4.21 \\
\hline
\end{tabular}

Adsorbent yield is inversely proportional to waste minimization. In other words, a low adsorbent yield was desirable because it implied using a large amount of waste to produce one kilogram of adsorbent. Yields are calculated based on the relationship between the quantity or mass of the final product obtained and the quantity or mass of its precursor (dry peel) used at the beginning of the process. An ANOVA revealed that the three treatments reported significantly different yields $(p<0.05)$. The performance of each treatment was then contrasted against the complexity of the process required for obtaining the corresponding adsorbent. Treatment S01 reported the highest average yield. This treatment was adapted from Moreno Marenco [45], who did not report the performance values for the adsorbents prepared using coffee grounds and shrimp exoskeletons. The S02 adsorbent was prepared using a methodology similar to the one used by Marshall et al. [2]. The S02 yield was lower than the McLaren Vale grape stalk adsorbent yields reported by Marshall et al. [2] (32.5\%). The process was conducted under similar conditions and at the same carbonization temperature. The present results were different because of the high moisture content in sanky peel [19], which generated a low proportion of solids in the peel-drying process and, consequently, a low adsorbent yield. The S03 treatment reported the lowest yields, and it was the most complex procedure. It required more time, more middle steps, and from the environmental perspective, it was the least eco-friendly as it used chemical solvents for a chemical pretreatment $\left(\mathrm{NaOH}\right.$ at $0.1 \mathrm{~N}$ and $\mathrm{H}_{2} \mathrm{SO}_{4}$ at $\left.0.1 \mathrm{~N}\right)$ as well as chemical activation $\left(\mathrm{H}_{2} \mathrm{SO}_{4}\right.$ at $80 \%$ and $\mathrm{NaHCO}_{3}$ at $\left.10 \%\right)$. Furthermore, the S03 yields were affected by $\mathrm{H}_{2} \mathrm{SO}_{4}$ in the adsorbent material pretreatment. This acid exhibited corrosive and reactive properties when it met the dehydrated sanky peels. Moreover, the concentrated sulfuric acid $\left(\mathrm{H}_{2} \mathrm{SO}_{4}\right.$ at $\left.80 \%\right)$ had a similar corrosive behavior with the 
previously dried material mass. Additionally, sulfuric acid is on the list of products subject to control and supervision in the Peruvian territory [46]. In the production of S03, considerable energy was consumed as it required oven drying before chemical activation and subsequent oven drying before muffle carbonization. This method was adapted from Yadav et al. [25], who used fruit juice and rice husk waste as adsorbents.

The assessment of manufacturing costs required estimating raw material prices, the current Peruvian minimum wage, current potable water rates, and other utility rates, such as sewerage and electricity. Raw material prices included sanky peel drying costs. The prices of the chemical reagents were obtained from the corresponding vendors. Some authors reported that adsorbents are usually inexpensive provided they are prepared from natural materials available in large quantities, require little processing, or are a byproduct or agricultural waste [47-49]. Most studies do not provide information on manufacturing costs.

In terms of their cost, adsorbents are classified into the following: (i) low cost: adsorbents that cost significantly lower than US\$/kg 1; (ii) middle cost: adsorbents that generally cost between US\$/kg 3 and 6; (iii) high cost: adsorbents that cost between US\$/ kg 15 and 20 [50]. According to this cost classification, S01 was somewhere between a low- and middle-cost adsorbent. S02 was between a middle- and high-cost adsorbent. S03 exceeded high-cost adsorbents. Compared against chitosan prices (US\$/kg 16) [51], S01, S02, and S03 are equivalent in cost to $15.6 \%, 81.5 \%$, and $285.75 \%$, respectively. Similarly, when comparing against the costs of Filtrasorb 400 activated carbon (Calgon Carbon Corp., Pittsburgh, PA, USA) (US\$/kg 20-22) [51], S01, S02, and S03 represent 11.3-12.5\%; 59.3-65.2\%, and 207.8-228.6\%, respectively. In fact, S01 has a competitive cost, well below the price of commercial adsorbents. S02 also has a competitive cost, slightly lower than the price of commercial adsorbents, whereas S03 is very expensive compared to the price of commercial adsorbents, which renders it out of the competition.

The aqueous solution with the presence of phosphate in calcium ions was kept in contact with the adsorbent for a week at room temperature. Adding calcium helps in the adsorption of organic materials from water at certain $\mathrm{pH}$ values [52]. Moreover, calcium is one of the cations often present in sewage streams, which facilitates the recovery of phosphates owing to its abundance [2]. The S01 treatment released phosphate during the experiment. The phosphate released from the adsorbent structure [53] increased the phosphate concentration in the solution. The adsorbent materials S02 and S03 also managed to remove phosphate from the aqueous solution under the conditions studied. The average S03 phosphate removal values are significantly higher than S02 $(p<0.05)$. The greater phosphate removal capabilities exhibited by the $\mathrm{S} 03$ adsorbent were caused by sulfuric acid being used in the chemical activation process, which increased the cracking of the material's structure and increased the adsorbent surface [37]. Surface area is an important physical property that influences the adsorbents adsorption capacity [6].

Physical Adsorption of Nitrogen. The BET surface $\left(S_{\mathrm{BET}}\right)$, microporous surface $\left(S_{\mathrm{mi}}\right)$, external surface $\left(S_{\text {ext }}\right)$, and microporous volume $\left(V_{\mathrm{mi}}\right)$ were all evaluated using the t-plot method. The mean pore diameter, $\left(D_{\mathrm{p}}\right)$, was estimated using the BarrettJoyner-Halenda $(\mathrm{BJH})$ method from $D p=4 V T / S$, where $V T$ is the total pore volume. Herein, S01 did not exhibit textural characteristics for adsorption. However, both S02 and S03 exhibited high pyrolysis temperature, which contributed to the formation of pores and, consequently, to a greater surface area [6]. The increase in micropore volume is caused by the removal of volatile organic components at high temperatures [54]. The BET surface in $\mathrm{S} 02$ was similar to the surface reported for functionalized grapefruit peel $\left(S_{\mathrm{BET}}=9.6 \mathrm{~m}^{2} \mathrm{~g}^{-1}\right)$ [37]. $\mathrm{S} 02$ had higher $S_{\mathrm{BET}}$ value than chitosan-encapsulated magnetic kaolin beads $\left(S_{\mathrm{BET}}=2.12 \mathrm{~m}^{2} \mathrm{~g}^{-1}\right)$ [55]. S02 also presented a larger microporous structure than S03. This indicated that adsorption in S02 occurred by filling the micropore volume [52]. The $V T$ parameter for $\mathrm{S} 02$ was similar to the $V T$ parameter for chitosanencapsulated magnetic kaolin beads $\left(V T=0.23 \mathrm{~cm}^{3} \mathrm{~g}^{-1}\right)$ [55]. However, unlike this 
adsorbent material, the $\mathrm{S} 02$ treatment had a simpler preparation process, without the use of chemical substances.

The particle size of the adsorbents (size $\leq 0.35 \mathrm{~mm}$ ) was in the recommended range for granular activated carbons $(0.3-2 \mathrm{~mm})$ [56]. The moisture content of the adsorbents was calculated using the standard method (ASTM D2867-17). Humidity must not exceed $8 \%$ according to the AWWA standard for granular activated carbon [56]. In this regard, the S02 and S03 moisture contents comply with the recommendation for granular activated carbon in the AWWA standards (humidity $<8 \%$ ), but $\$ 01$ exceeds this value, which reduces its quality.

The ash content of the adsorbents was also determined using the standard method (ASTM D2866-11). Regarding ash content, the mineral amount present in an adsorbent indicates its value. It is an important quality factor in the use of activated carbons because these minerals could contaminate the product being purified 52]. The higher the ash content, the lower the material adsorption capacity [57]. The ash content in S01 was just the ground dried sanky peel ash [19]. The ash content values determined for S02 and S03 were similar to the ash content values reported for activated fruit juice waste $(5.047 \%)$ and activated rice husk (4.8\%) by Kumar et al. [58].

The alkaline $\mathrm{pH}$ of both $\mathrm{S} 02$ and S03 favor phosphate elimination conditions [59]. These $\mathrm{pH}$ values indicated that the $\mathrm{S} 02$ and $\mathrm{S} 03$ surface composition mainly comprise basic surface groups, pyrone, chromene, and delocalized $\pi$ electrons in the adsorbent layers [60].

In material selection, the characteristics exhibited by $\mathrm{S} 01$ rendered it the least preferred; it presented the highest moisture content, high yields (less waste minimization), high ash content, lacked a BET surface, and mainly, it did not manifest adequate phosphate adsorption capacities. Conversely, this material released phosphate in aqueous solution under the conditions evaluated. Both $\mathrm{S} 02$ and $\mathrm{S} 03$ exhibited better adsorbent characteristics. However, the cost of $\mathrm{S} 03$ was high, rendering it out of the competition when compared to commercially available adsorbents. Moreover, the process of obtaining S03 was complex, with high energy consumption and use of chemical substances, which made it less ecofriendly. Given these results, the preferred material selected for further testing was S02.

Boehm Titration-Determination of Active Site. Adsorbents that have acidic surface groups exhibit cation exchange properties. In contrast, adsorbents with low oxygen content manifest basic surface properties and exchange anions [32]. The S02 treatment presented a higher concentration of acidic surface groups $\left(45.89 \mathrm{mmole}^{-1}\right.$ ) than that of basic surface groups $\left(6.67 \mathrm{mmole}^{-1}\right)$. This hindered phosphate anion adsorption, thus requiring the addition of calcium ions to the solution.

Point of Zero Charge. The $\mathrm{pH}$ value at which the net charge on the $\mathrm{S} 02$ surface is zero was 8.1 units. The regression equation was $\Delta \mathrm{pH}=6.286-0.7774 \mathrm{pH}_{\text {initial }}$. This suggests that phosphate adsorption occurs when the $\mathrm{pH}$ level of the solution is below 8.1 because the surface must be positively charged and the phosphate in its anionic form. In this study, phosphate adsorption occurred at $\mathrm{pH} 6.5$ and 9.0 below and above the PZC. This revealed that correlating the content of active sites with PZC is impossible [61].

The PZC value in S02 was similar to the PZC value reported for Filtrasorb 400 PZC activated carbon (8.82) [62]. The latter is used in applications such as drinking water purification processes, wastewater treatment, as well as food, pharmaceuticals, and industrial purification.

Infrared Spectroscopy (FTIR). We conducted FTIR studies with the adsorbent material both before and after phosphate adsorption. After adsorption, the adsorbent was filtered and dried at $60{ }^{\circ} \mathrm{C}$ until reaching a constant weight [63]. The adsorption capacity of activated carbon is determined by its porous structure and is strongly influenced by the chemical structure of the adsorbent surface [52]. The FTIR spectra are presented in Figure 3. In Figure 3d, the peak changes from 1568.60 to 1580.21 , which can be attributed to the phosphate released at $\mathrm{pH}=4.0$. Figure $3 \mathrm{~b}, \mathrm{c}$ indicate the appearance of new peaks at 872.91 and $872.31 \mathrm{~cm}^{-1}$, respectively, which are related to the stretching vibrations of the $\mathrm{O}-\mathrm{P}-\mathrm{O}$ bonds [64]. Moreover, new peaks appeared at $1029.92 \mathrm{~cm}^{-1}$ and 1396.89 (Figure 3b) and 
$1026.34 \mathrm{~cm}^{-1}$ and 1397.22 (Figure 3c). These new bands are related to the $\mathrm{HPO}_{4}{ }^{2-}$ vibrations and brushite spectrum [65]. The FTIR study supports the synthesis of brushite owing to the presence of calcium ions [2]. The calcium cation was adsorbed by the phosphate-loaded adsorbent, thus causing the brushite formation on the adsorbent surface [65]. Calcium was adsorbed on short-range ordered graphitic sheet edges through the interaction of ions with oxygen-containing functional species located in the adsorbent with brushite acting as seed material for the formation of a slatted calcium phosphate ion [2]. The phosphate adsorption capacity at $\mathrm{pH} 6.5$ and 9.0 in $\mathrm{S} 02$ was directly linked to the interaction between the calcium cation on its surface and phosphate from the solution.

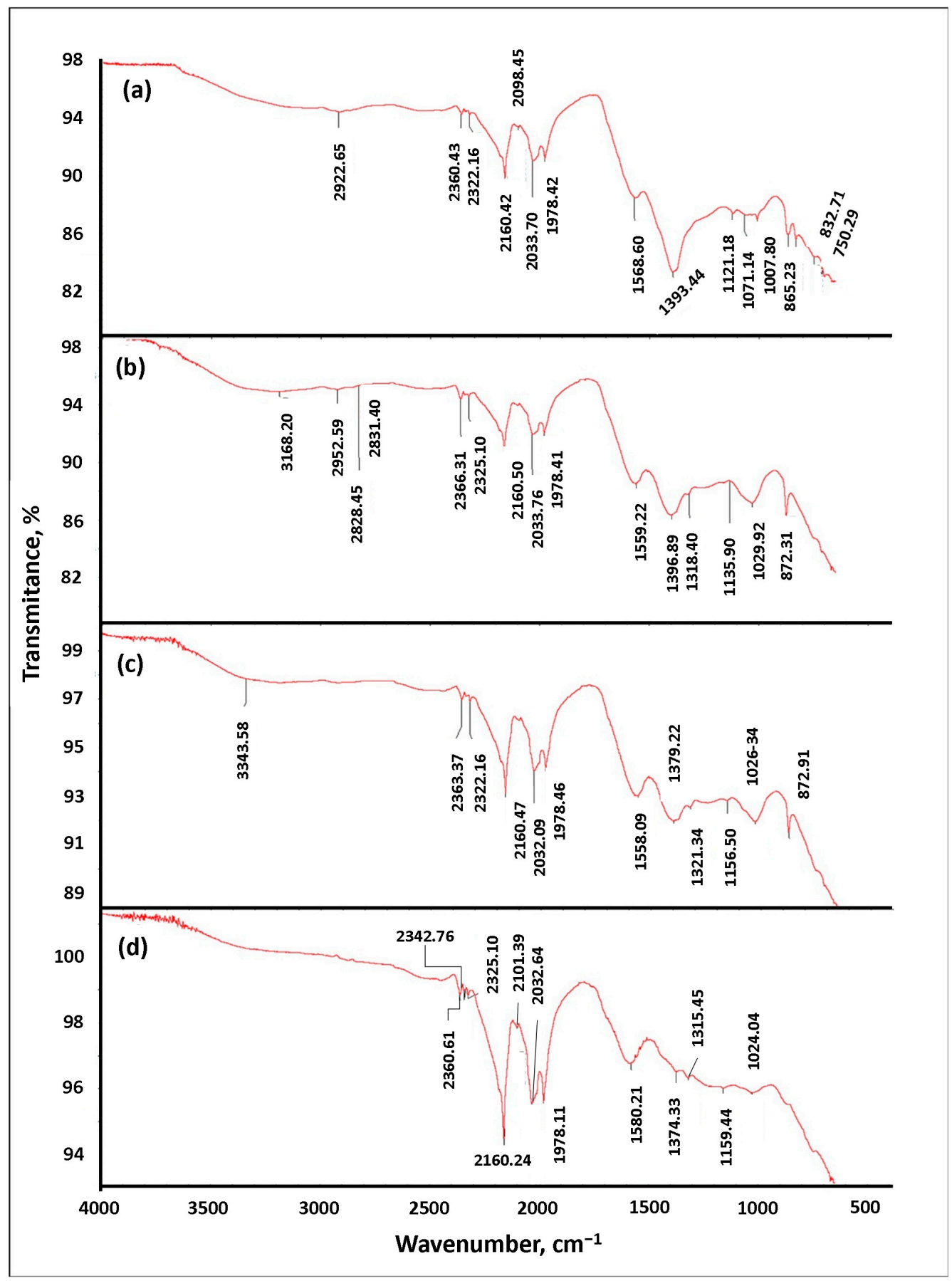

Figure 3. FT-IR spectrum of S02 before adsorption (a). FT-IR spectrum of S02 after phosphate adsorption at $\mathrm{pH} 9.0$ (b); $\mathrm{pH} 6.5$ (c) and $\mathrm{pH} 4.0$ (d). Initial phosphate concentration $10 \mathrm{mg} / \mathrm{L}$, temperature $\left(25.8^{\circ} \mathrm{C}\right.$ and $\left.81.6 \% \mathrm{RH}\right), 1$ week. 
Batch Adsorption. A batch adsorption experiment was conducted in Erlenmeyer flasks. This experiment assessed the optimum $\mathrm{pH}$ conditions and initial phosphate concentrations to achieve the maximum phosphate removal efficiency (\%) and phosphate adsorption capacity $\left(\mathrm{mg} \mathrm{g}^{-1}\right)$. As our data did not meet the statistical assumptions in the ANOVA conducted, we performed a nonparametric Kruskal-Wallis test at a 5\% significance level, wherein the $\mathrm{pH}$ level, initial phosphate concentration, and $\mathrm{pH}^{*}$ initial phosphate concentration factors were used to determine phosphate removal efficiency and phosphate adsorption capacity.

The $\mathrm{pH}$ level of the solution indicated the presence of phosphate hydroxyl groups $\left(\mathrm{H}_{3} \mathrm{PO}_{4}, \mathrm{H}_{2} \mathrm{PO}_{4}{ }^{-}, \mathrm{HPO}_{4}{ }^{2-}\right.$, and $\left.\mathrm{PO}_{4}{ }^{3-}\right)$, which is one of the most important parameters that influence the phosphate adsorption process [66]. This study revealed that the adsorptive property of S02 was sensitive to $\mathrm{pH}$ level. Moreover, its phosphate removal efficiency (\%) and phosphate adsorption capacity $\left(\mathrm{mg} \mathrm{g}^{-1}\right)$ were significantly different $(p<0.05)$ at a $\mathrm{pH}$ of 4 . The adsorbent released phosphate at $\mathrm{pH} 4$ and exhibited adsorbent activity at $\mathrm{pH} 6.5$ and 9.0. The $\mathrm{pH}$ of the aqueous solution also altered the adsorbent loads. The dissociation of functional groups in the active site of the adsorbent and degree of ionization of the adsorbate [67] may explain the release of phosphate at $\mathrm{pH} 4$.

When studying the effects from the initial phosphate concentration, the higher the initial phosphate concentration, the higher the phosphate removal efficiency $(p<0.05)$. The evaluation of the $\mathrm{pH}^{*}$ initial phosphate concentration factors revealed that the phosphate removal efficiency and phosphate adsorption capacity exhibited by $\mathrm{S} 02$ was significantly higher $(p<0.05)$ when the experiment was performed at a $\mathrm{pH}$ of 6.5 and at an initial phosphate concentration of $10 \mathrm{mg} \mathrm{L}^{-1}$. The adsorption capacity reached a maximum of $14.44 \mathrm{mg} \mathrm{g}^{-1}$, and the highest phosphate removal efficiency was $94.19 \%$.

\subsection{Adsorption Kinetics}

Both the phosphate removal efficiency $(\%)$ and phosphate adsorption capacity $\left(\mathrm{mg} \mathrm{g}^{-1}\right)$ were significantly different $(p<0.05)$ during the different contact times studied $(1,6,12$, $24,36,72$, and $168 \mathrm{~h}$ ). Figure 4 represents the adsorption kinetics of phosphates for S02. According to this figure, as the equilibrium was reached at $168 \mathrm{~h}$, this was the time we used for the other adsorption tests. The study showed significant effects $(p<0.05)$ of adsorbent contact time on the phosphate removal efficiency and phosphate adsorption capacity $\left(\mathrm{mg} \mathrm{g}^{-1}\right)$, reaching the maximum values at $168 \mathrm{~h}$, both at $\mathrm{pH} 6.5$ and 9.0.

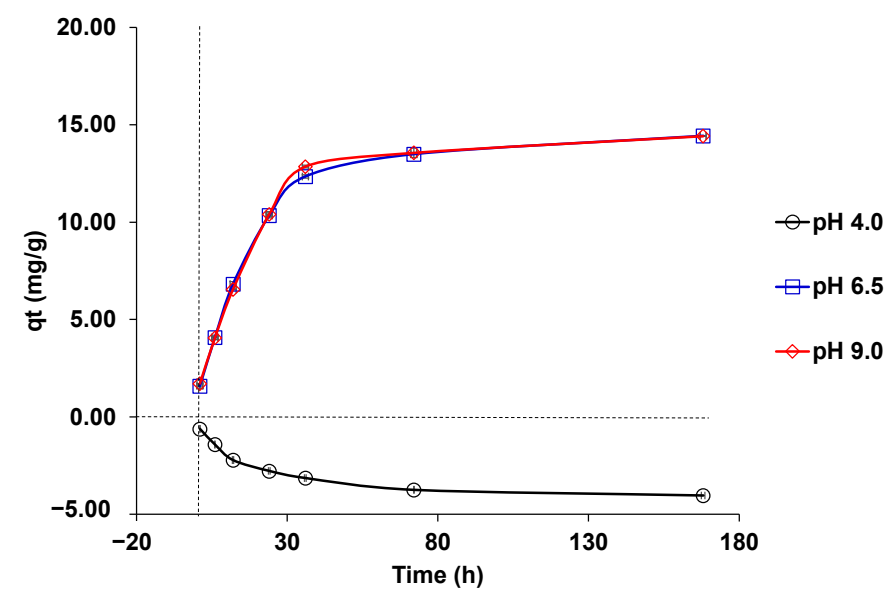

Figure 4. Kinetics of phosphate adsorption in $\mathrm{S} 02$ at different $\mathrm{pH}$ solutions $(\mathrm{pH}=4.0(\bigcirc), 6.5(\square)$ and $9.0(\diamond)$. Experimental conditions: initial phosphate concentration $(10 \mathrm{mg} / \mathrm{L})$; adsorbent dose $(50 \mathrm{mg})$; solution volume $(25 \mathrm{~mL})$; calcium chloride concentration $(1.11 \mathrm{~g} / \mathrm{L})$, sodium azide concentration $(1 \mathrm{~g} / \mathrm{L})$, and room temperature. 


\subsection{Kinetic Modeling}

Four kinetic models were tested to obtain the best data correlation: the pseudo-firstorder, pseudo-second-order, Elovich, and Weber-Morris models. Figure 5 presents the linear adjustment charts for the kinetic models studied. The regression equations obtained when evaluating the data fit for each kinetic model studied are provided in Table S1, and the parameters calculated for each model are presented in Table S2. Furthermore, to verify the suitability of these kinetic models, we determined their coefficient of determination $\left(R^{2}\right)$, adjusted $R^{2}$, Chi-squared $\left(\chi^{2}\right)$, sum squared error (SSE), mean square error (MSE), and hybrid fractional error function (HYBRID).
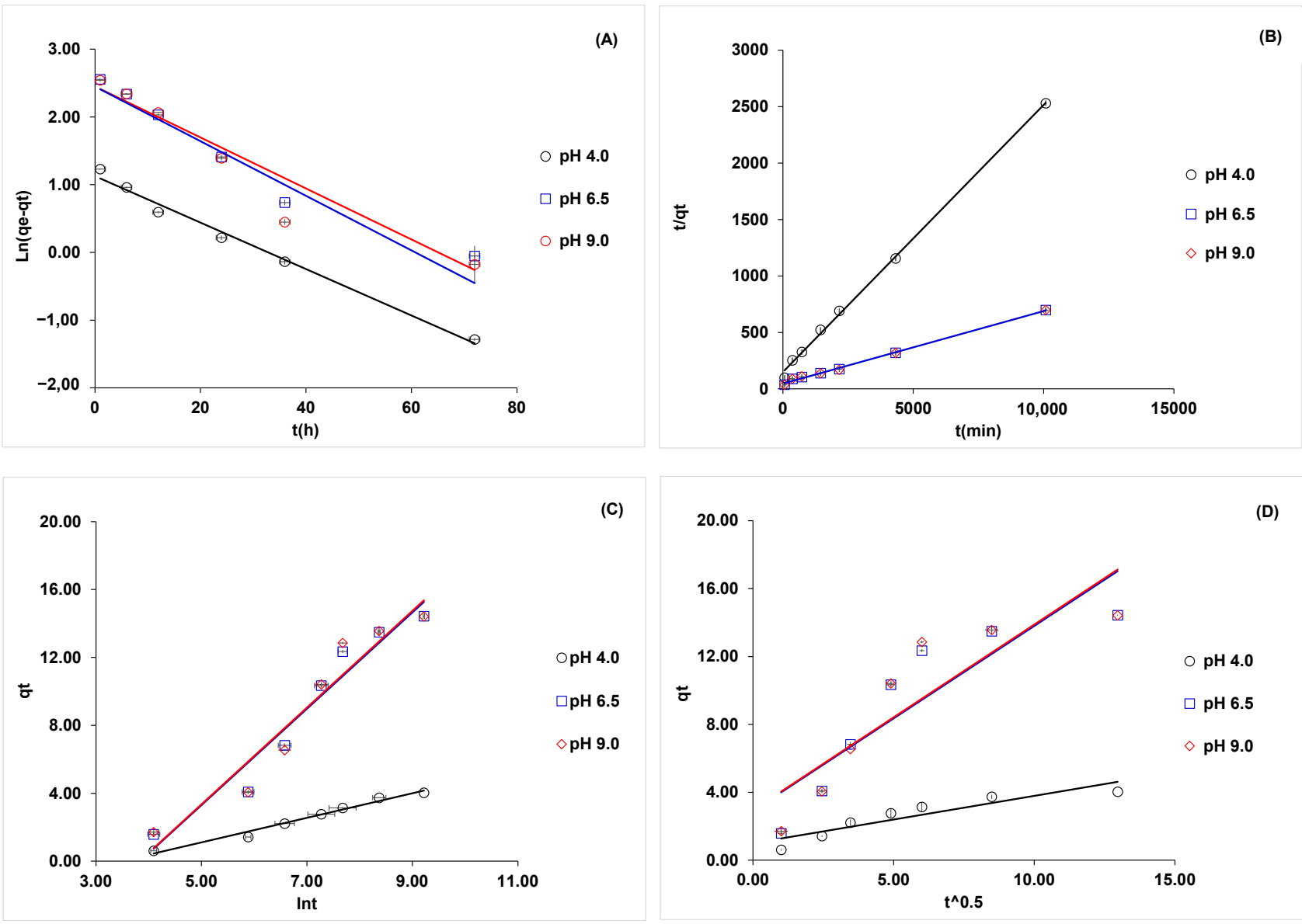

Figure 5. Fitting of the experimental data of phosphate adsorption in $\mathrm{S} 02$ for kinetic models at different $\mathrm{pH}$ solutions $(\mathrm{pH}=4.0$ $(\bigcirc) ; 6.5(\square)$ and $9.0(\diamond))$. (A) Pseudo-first-order, (B) pseudo-second-order, (C) Elovich model, and (D) Weber-Morris model.

The estimated values of $R^{2}$, adjusted $R^{2}$, and MSE suggested that the pseudo-secondorder, Elovich, and Weber-Morris models were the best fit. The pseudo-first-order model did not have a good fit. The SSE values for the pseudo-second-order and Elovich kinetic models were less than one, suggesting a good fit. The SSE for the pseudo-first-order and Weber-Morris models indicated that the fit was not good. Finally, according to the HYBRID values, the model that best adjusted to the experimental data was the pseudo-second-order as it indicated that two active sites on the adsorbent can be occupied by the same phosphate ion [68].

The speed constants predicted by the Elovich model were the highest $(0.352$ and $0.351 \mathrm{mg} \mathrm{g}^{-1} \mathrm{~min}^{-1}$ at $\mathrm{pH}=6$ and 9, respectively). This parameter defines the time the chemical process requires to complete [69]. The $q_{e}$ values estimated with the pseudosecond-order model were similar to the results from the experimental $q_{e}$. The adsorption process was based on chemisorption [34]. 


\subsection{Adsorption Isotherms}

From the experimental data, the linear graph equations for the Langmuir, Freundlich, and Dubinin-Radushkevich isotherm models were obtained and are shown in Table 3. The parameters, constants, coefficients of determination $\left(R^{2}\right)$, and adjusted $R^{2}$ obtained from the three models are summarized in Table 4.

Table 3. Regression equation for the Langmuir, Freundlich and Dubinin-Radushkevich isotherms using the adsorbents derived from the sanky peel (S02) in aqueous phosphate solution at different $\mathrm{pH}$.

\begin{tabular}{cccc}
\hline \multirow{2}{*}{ Model } & \multicolumn{1}{c}{$\mathbf{p H}$} & $\mathbf{9 . 0}$ \\
\cline { 2 - 4 } & $\mathbf{4 . 0}$ & $\mathbf{6 . 5}$ & $\frac{C_{e}}{q_{e}}=-0.5449 C_{e}+0.3514$ \\
Langmuir & $\frac{C_{e}}{q_{e}}=0.3107 C_{e}+0.7603$ & $\frac{C_{e}}{q_{e}}=-0.5098 C_{e}+0.3263$ & $\log q_{e}=1.809+3.036 \log C_{e}$ \\
Freundlich & $\log q_{e}=1.114-0.472 \log C_{e}$ & $\log q_{e}=1.804+2.929 \log C_{e}$ & $\log q_{e}$ \\
Dubinin-Radushkevich & $\ln q_{e}=1.055+0.0017 \varepsilon^{2}$ & $\ln q_{e}=6.5968-0.0016 \varepsilon^{2}$ & $\ln q_{e}=6.7353-0.0017 \varepsilon^{2}$ \\
\hline
\end{tabular}

Table 4. Regression equation for the Langmuir, Freundlich and Dubinin-Radushkevich isotherms using the adsorbents derived from the sanky peel (S02) in aqueous phosphate solution at different $\mathrm{pH}$.

\begin{tabular}{|c|c|c|c|c|}
\hline \multirow{2}{*}{ Model } & \multirow{2}{*}{ Parameter } & \multicolumn{3}{|c|}{$\mathrm{pH}$} \\
\hline & & 4.0 & 6.5 & 9.0 \\
\hline \multirow{5}{*}{ Langmuir } & qmax (mg/g) & -3.22 & -1.96 & -1.84 \\
\hline & $k_{L}(\mathrm{~L} / \mathrm{mg})$ & -2.45 & -0.63 & -0.64 \\
\hline & $\mathrm{R}_{\mathrm{L}}$ & -0.69 & 2.69 & 2.82 \\
\hline & $\mathrm{R}^{2}$ & 0.793 & 0.996 & 0.996 \\
\hline & $\mathrm{R}^{2}$ ajusted & 0.173 & 0.982 & 0.982 \\
\hline \multirow{4}{*}{ Freundlich } & $\mathrm{K}_{\mathrm{F}}$ & 13.00 & 63.80 & 64.46 \\
\hline & $\mathrm{n}$ & -2.12 & 0.34 & 0.19 \\
\hline & $\mathrm{R}^{2}$ & 0.878 & 0.949 & 0.888 \\
\hline & $\mathrm{R}^{2}$ ajusted & 0.512 & 0.796 & 0.550 \\
\hline \multirow{5}{*}{$\begin{array}{l}\text { Dubinin- } \\
\text { Radushkevich }\end{array}$} & $\mathrm{q}_{\max }(\mathrm{mg} / \mathrm{g})$ & 1.06 & 6.60 & 6.74 \\
\hline & $\beta\left(\mathrm{mol}^{2} \mathrm{~kJ}^{-2}\right)$ & -0.0017 & 0.0019 & 0.0020 \\
\hline & $\mathrm{E}(\mathrm{kJ} / \mathrm{mol})$ & & 16.2 & 15.8 \\
\hline & $\mathrm{R}^{2}$ & 0.912 & 0.987 & 0.988 \\
\hline & $R^{2}$ ajusted & 0.648 & 0.948 & 0.951 \\
\hline
\end{tabular}

The separation factor $R_{\mathrm{L}}>1$ at $\mathrm{pH} 6.5$ and 9.0 indicated that the adsorption was unfavorable and did not conform to the Langmuir model. The $\frac{1}{n}>1$ value also suggested that adsorption did not conform to the Freundlich model [70]. The data were fitted to the Dubinin-Radushkevich model. The mean adsorption free energy $(E)$ values were 16.2 and $15.8 \mathrm{~kJ} \mathrm{~mol}^{-1}$ at the $\mathrm{pH}$ values of 6.5 and 9.0, respectively. The adsorption process is related to filling the total volume of S02 micropores [71], which assumes a multilayer structure wherein Van der Waals forces are engaged [42]. The results from the isotherm confirms that adsorption occurs through ion exchange, given the $8 \mathrm{KJ} / \mathrm{mol}<E<16 \mathrm{KJ} / \mathrm{mol}$ value [72].

\subsection{Comparison of the Adsorption Capacity with the Adsorbents Reported in the Literature}

The comparison of the $\mathrm{S} 02$ adsorption efficiency against other adsorbents is depicted in Table 5. Li et al. [73] and Xiong et al. [74] studied the adsorption capacity of powdered activated carbon and zirconium and iron oxides on activated carbon nanofibers, respectively, achieving good phosphate adsorption capacity at acidic $\mathrm{pH}$ levels. This suggests that, at $\mathrm{pH}=4$, calcium was not adsorbed by S02; therefore, neither phosphate was adsorbed nor brushite synthesized. Alternatively, Nan et al. [75] investigated the adsorption capacity of activated carbon derived from rice husk $\left(6.93 \mathrm{mg} \mathrm{g}^{-1}\right)$, obtaining a lower adsorption capacity than $\mathrm{SO2}$ despite using a higher dose of adsorbent at a neutral $\mathrm{pH}$ level. Rashid et al. [76] studied magnetite nanoparticles coated with humic acid with a 
more complex preparation process. They obtained a material with a larger surface area and greater phosphate adsorption capacities $\left(28.9 \mathrm{mg} \mathrm{g}^{-1}\right)$ at a lower adsorbent dose and neutral pH level. The S02 adsorption capacity was lower than the biochar developed by Marshall et al. [2] (25.9 $\left.\mathrm{mg} \mathrm{g}^{-1}\right)$ in the same adsorption conditions.

Table 5. Phosphate adsorption efficiencies among different adsorbents.

\begin{tabular}{|c|c|c|c|c|c|}
\hline Adsorbent & Doses & $\mathrm{pH}$ & Temperature $\left({ }^{\circ} \mathrm{C}\right)$ & $q_{\mathrm{t}}\left(\mathrm{mg} \mathrm{g}^{-1}\right)$ & Reference \\
\hline Sanky Shell Adsorbent (S02) & $0.05 \mathrm{~g}$ adsorbent $/ 25 \mathrm{~mL}$ & 6.5 & 25 & 14.44 & \multirow{2}{*}{$\begin{array}{l}\text { This work } \\
\text { [73] }\end{array}$} \\
\hline Powdered Activated Carbon & $0.02 \mathrm{~g}$ adsorbent $/ 30 \mathrm{~mL}$ & 3.6 & 20 & 16.86 & \\
\hline $\begin{array}{c}\text { Zirconium Oxide and Iron Oxide on Activated } \\
\text { Carbon Nanofibers }\end{array}$ & $0.3 \mathrm{~g}$ adsorbent $/ 300 \mathrm{~mL}$ & 4.0 & 25 & 26.3 & [74] \\
\hline Activated Carbon Derived from Rice Husk & $0.2 \mathrm{~g}$ adsorbent $/ 50 \mathrm{~mL}$ & 7.0 & 25 & 6.93 & [75] \\
\hline $\begin{array}{c}\text { Humic Acid Coated with Magnetite } \\
\text { Nanoparticles }\end{array}$ & $0.05 \mathrm{~g}$ adsorbent $/ 50 \mathrm{~mL}$ & 6.6 & 25 & 28.9 & [76] \\
\hline Biochar from Grape Stalks Charred at $500{ }^{\circ} \mathrm{C}$ & $0.05 \mathrm{~g}$ adsorbent $/ 25 \mathrm{~mL}$ & 6.5 & 25 & 25.9 & [2] \\
\hline
\end{tabular}

The comparison results reveal that S02 is competitive in the adsorption of aqueous phosphate at neutral and alkaline $\mathrm{pH}$ values and can potentially be used as an efficient adsorbent for removing phosphates from water.

\section{Conclusions and Future Perspectives}

This study produced an adsorbent using sanky peel, a wild Andean fruit from a vulnerable species, for the adsorption of phosphate from a calcium-ion aqueous solution through a batch adsorption process. For these purposes, three adsorbent-preparation treatments were tested, followed by selecting the adsorbent whose preparation process was environmentally friendly and competitive with existing commercial adsorbents, had good textural characteristics, and had proven effective for phosphate removal from aqueous solutions. The best phosphate adsorption conditions were at a $\mathrm{pH}$ level of 6.5 and an initial phosphate concentration of $10 \mathrm{mg} \mathrm{L}^{-1}$, with a phosphate removal efficiency of $94.2 \%$ and an adsorption capacity of $14.44 \mathrm{mg} \mathrm{g}^{-1}$. The experiments revealed that the material released phosphate at a $\mathrm{pH}$ level of 4 and that the time required for phosphate adsorption to reach equilibrium was $168 \mathrm{~h}$. The parameters obtained from the kinetic studies demonstrated that the adsorption process best abided by the pseudo-second-order kinetics, followed by the Elovich and Weber-Morris models. Phosphate adsorption was best described through the Dubinin-Radushkevich isotherm. The adsorption efficiency of the sanky peel adsorbent is comparable to commercial powdered activated carbon for treating nutrient-rich water containing phosphates at a neutral $\mathrm{pH}$ level. Moreover, the sanky peel adsorbent also presents other advantages, such as eco-friendliness, economic development opportunities, the possibility of improving the quality of life in Andean communities, and protecting endangered species, which make this adsorbent a good alternative for aqueous phosphate adsorption. On the other hand, future perspectives include studies of the removal of other wastewater pollutants.

Supplementary Materials: The following are available online at https:/ / www.mdpi.com/article/10 .3390/su13168994/s1, Table S1: Regression equation for the four kinetic models studied, Table S2: Kinetic parameters for phosphate sorption for sanky peel derived adsorbent at different $\mathrm{pH}$.

Author Contributions: Conceptualization, E.C.-L. and V.M.K.; methodology, E.C.-L.; software, M.P.-M.; validation, E.C.-L., J.P.C. and M.P.-M.; formal analysis, E.C.-L.; investigation, E.C.-L., V.M.K. and J.P.C.; resources, R.Y.-P.; data curation, R.Y.-P.; writing-original draft preparation, E.C.-L. and F.R.-E.; writing - review and editing, F.R.-E. and A.M.M.; visualization, A.M.M.; supervision, H.G.-T.; project administration, R.Y.-P.; funding acquisition, E.C.-L. and A.M.M. All authors have read and agreed to the published version of the manuscript.

Funding: This research was funded by Vicerrectorado de Investigación y Posgrado-Universidad Nacional Mayor de San Marcos grant number A18041891 and the APC was funded by Universidad San Ignacio de Loyola. 
Institutional Review Board Statement: Not applicable.

Informed Consent Statement: Not applicable.

Acknowledgments: To Eng. Ciro Calle Pacheco, for providing us with the fruits (sanky). To our collaborators Alessandra Arosena, Ruth Chávez and Eida Quispe.

Conflicts of Interest: The authors declare no conflict of interest.

\section{References}

1. Damania, R.; Desbureaux, S.; Rodella, A.-S.; Russ, J.; Zaveri, E. Quality Unknown: The Invisible Water Crisis; World Bank: Washington, DC, USA, 2019.

2. Marshall, J.A.; Morton, B.J.; Muhlack, R.; Chittleborough, D.; Waikwong, C. Recovery of phosphate from calcium-containing aqueous solution resulting from biochar-induced calcium phosphate precipitation. J. Clean. Prod. 2017, 165, 27-35. [CrossRef]

3. Bolaños-Alfaro, J.D.; Cordero-Castro, G.; Segura-Araya, G. Determinación de nitritos, nitratos, sulfatos y fosfatos en agua potable como indicadores de contaminación ocasionada por el hombre, en dos cantones de Alajuela (Costa Rica). Tecnol. Marcha 2017, 30, 15-27. [CrossRef]

4. Roy-Poirier, A. Bioretention for Phosphorus Removal: Modelling Stormwater Quality Improvements; Universidad de la reina en Kingston: Kingston, ON, Canada, 2009.

5. Xie, Q.; Li, Y.; Lv, Z.; Zhou, H.; Yang, X.; Chen, J.; Guo, H. Effective adsorption and removal of phosphate from aqueous solutions and eutrophic water by Fe-based MOFs of MIL-101. Sci. Rep. 2017, 7, 3316. [CrossRef] [PubMed]

6. Tareq, R.; Akter, N.; Azam, M.S. Biochars and biochar composites: Low-cost adsorbents for environmental remediation. In Biochar from Biomass and Waste; Elsevier: Amsterdam, The Netherlands, 2019; pp. 169-209.

7. Wang, W.; Huang, G.; An, C.; Zhao, S.; Chen, X.; Zhang, P. Adsorption of anionic azo dyes from aqueous solution on cationic gemini surfactant-modified flax shives: Synchrotron infrared, optimization and modeling studies. J. Clean. Prod. 2018, 172, 1986-1997. [CrossRef]

8. Pujante, A.M. Valorización de Residuos Sólidos de Lodos de Purín Mediante la Obtención de Carbón Activo; Universitat Politècnica de València: Valencia, Spain, 2016; Available online: https:/ / riunet.upv.es/handle/10251/68389 (accessed on 4 June 2021).

9. Camero, C.R.L. Efecto Hepatoprotector del Zumo del Fruto de Corryocactus Brevistylus (Sanky) en Ratones con Daño Hepático Inducido por Etanol; Universidad Nacional Mayor de San Marcos: Lima, Peru, 2016.

10. Cáceres, F.; Roque, J.; Ostalaza, C.; Walter, H.E. Corryocactus brevistylus (Amended Version of 2013 Assessment). In The IUCN Red List of Threatened Species; Santiago de Chile, Chile. 2017. Available online: https:/ / www.iucnredlist.org/species/152049/1214561 67 (accessed on 27 May 2021).

11. Ostolaza, C.N. Todos los Cactus del Perú; Ministerio del Ambiente: Lima, Perú, 2014.

12. Pauca, A.; Quipuscoa, V. Catálogo de las cactáceas del departamento de Arequipa, Perú. Arnaldoa 2017, 24, 447-496. [CrossRef]

13. Arakaki, M.; Ostolaza, C.; Caceres, F.; Roque, J. Cactaceae endémicas del Perú. Rev. Peru. Biol. 2006, 13, 193-219. [CrossRef]

14. Municipalidad-Distrital-de-Saisa. Plan de Desarrollo Concertado local del Distrito de Saisa 2011-2121; Ayacucho, Perú, 2010. Available online: https:/ /leyes.congreso.gob.pe/Documentos/2016_2021/Consejo_Directivo/Documentos_Otras_Instituciones/OFICIO0201-2019-MDS-A.pdf (accessed on 10 May 2021).

15. SERFOR. SERFOR Promueve Plantaciones de Especie Nativa Medicinal "Sanky" en Comunidades Campesinas de Ica y Huancavelica. 2016. Available online: https:/ / www.serfor.gob.pe/portal/noticias/forestal/serfor-promueve-plantaciones-de-especienativa-medicinal-sanky-en-comunidades-campesinas-de-ica-y-huancavelica (accessed on 3 May 2021).

16. GOB.REG.-HVCA. Aprobación y Ampliación del Plazo del Proyecto Recuperación del Servicio Ambiental a Través de la Especie Corryocactus Brevistylus (Sanky) en las Provincias de Castrovirreyna y Huaytará Departamento de Huancavelica; Resolución Gerencial General Regional 131-2028/GOB.REG.-HVCA/GGR; Gobierno Regional de Huancavelica: Huancavelica, Peru, 2018.

17. Lima, D.O.; Crouzeilles, R.; Vieira, M.V. Integrating strict protection and sustainable use areas to preserve the Brazilian Pampa biome through conservation planning. Land Use Policy 2020, 99, 104836. [CrossRef]

18. Málaga Villanueva, C.N.; Rodríguez Coaguila, M.D.P. Proceso para la obtención de un Néctar Funcional a Partir de Sanky (Corryocactus Brevistylus) Maracuyá (Passiflora edulis), y agua Mineral Obtenida de Yura; Universidad Nacional de San Agustín: Arequipa, Perú, 2014; Available online: http:/ / repositorio.unsa.edu.pe/handle/UNSA/4189 (accessed on 2 July 2021).

19. Contreras-López, E.; Salvá Ruiz, B.K. Caracterización sensorial de hamburguesa de llama con cáscara de sanky. Rev. Investig. Altoandin 2018, 20, 155-168. [CrossRef]

20. Rojas, T.; Fuentes Campos, M.E.; Contreras-López, E.; Gómez, S.; Muñoz, A.M. Extracción asistida por ultrasonido de compuestos fenólicos de la cáscara de sanky (Corryocactus brevistylus). Rev. Soc. Quím. Perú 2019, 85, 258-267. [CrossRef]

21. Contreras-López, E.; Muñoz, A.M.; Salvá-Ruiz, B.K. Evaluación del extracto de cáscara de sanky en la estabilidad de carne de llama. Rev. Investig. Altoandin 2020, 22, 123-134. [CrossRef]

22. Rodríguez, N.O.; Cruz, A.; Collantes, I. Estudio de la Composición de los Ácidos Grasos Presentes en la Semilla, Cáscara y Pulpa del Corryocactus Brevistylus Subsp. Puquiensis; Congreso Iberoamericano de Química: Lima, Perú, 2018.

23. Municipalidad-Distrital-de-Saisa. Aprovechamiento Industrial del Sanky (Corryocactus brevistylus), de los Bosques Naturales en la Comunidad de Saisa, Distrito de Saisa, Provincia de Lucanas, Departamento Ayacucho; Municipalidad-Distrital-de-Saisa: Pasañe, Peru, 2009. 
24. Chaves Ávila, R.; Monzón Campos, J.L. La economía social ante los paradigmas económicos emergentes: Innovación social, economía colaborativa, economía circular, responsabilidad social empresarial, economía del bien común, empresa social y economía solidaria. CIRIEC Esp. Rev. Econ. Publica Soc. Coop. 2018, 93, 5-50. [CrossRef]

25. Yadav, D.; Kapur, M.; Kumar, P.; Mondal, M.K. Adsorptive removal of phosphate from aqueous solution using rice husk and fruit juice residue. Process. Saf. Environ. Prot. 2015, 94, 402-409. [CrossRef]

26. Londoño Carvajal, A.G.; Gómez, G.; Gutiérrez Gallego, A. Métodos Analíticos para la Evaluación de la Calidad Fisicoquímica del Agua; Universidad Nacional de Colombia: Manizales, Colombia, 2010; Available online: https:/ /repositorio.unal.edu.co/handle/unal/ 54604 (accessed on 5 June 2021).

27. Cooney, D.O. Adsorption Design for Wastewater Treatment; CRC Press: Boca Raton, FL, USA, 1998.

28. Lapham, D.P.; Lapham, J.L. Gas adsorption on commercial magnesium stearate: The origin of atypical isotherms and BET transform data. Powder Technol. 2019, 342, 676-689. [CrossRef]

29. ASTM. Standard Test. Methods for Moisture in Activated Carbon; ASTM International: West Conshohocken, PA, USA, 2017.

30. ASTM. Standard Test. Method for Total Ash Content of Activated Carbon; ASTM International: West Conshohocken, PA, USA, 2018.

31. ASTM. Standard Test. Method for $p H$ of Activated Carbon; ASTM International: West Conshohocken, PA, USA, 2017.

32. Boehm, H.P. Some aspects of the surface chemistry of carbon blacks and other carbons. Carbon 1994, 32, 759-769. [CrossRef]

33. Faria, P.; Orfao, J.; Pereira, M. Adsorption of anionic and cationic dyes on activated carbons with different surface chemistries. Water Res. 2004, 38, 2043-2052. [CrossRef]

34. Wang, J.; Guo, X. Adsorption kinetic models: Physical meanings, applications, and solving methods. J. Hazard. Mater. 2020, 390, 122156. [CrossRef]

35. Plazinski, W.; Rudzinski, W.; Plazinska, A. Theoretical models of sorption kinetics including a surface reaction mechanism: A review. Adv. Colloid Interface Sci. 2009, 152, 2-13. [CrossRef]

36. Ho, Y.-S.; McKay, G. Pseudo-second order model for sorption processes. Process. Biochem. 1999, 34, 451-465. [CrossRef]

37. Romero Cano, L.A. Preparación y Caracterización de Materiales Adsorbentes a Partir de Cáscaras de Frutas para su Uso en la Remoción de Metales y Aplicación a Procesos Ambientales; Universidad de Granada: Granada, Spain, 2018; Available online: https: / / digibug.ugr. es/handle/10481/49626 (accessed on 18 June 2021).

38. Elovich, S.Y.; Larionov, O. Theory of adsorption from nonelectrolyte solutions on solid adsorbents. Russ. Chem. Bull. 1962, 11, 191-197. [CrossRef]

39. Chien, S.; Clayton, W. Application of Elovich equation to the kinetics of phosphate release and sorption in soils. Soil Sci. Soc. Am. J. 1980, 44, 265-268. [CrossRef]

40. Nuñez, J.E.; Colpas, F.; Taron, A. Aprovechamiento de residuos maderosos para la obtencion de resinas de intercambio iónico. Temas Agrarios 2017, 22, 52-59. [CrossRef]

41. Foo, K.Y.; Hameed, B.H. Insights into the modeling of adsorption isotherm systems. Chem. Eng. J. 2010, 156, 2-10. [CrossRef]

42. Israel, U.; Eduok, U. Biosorption of zinc from aqueous solution using coconut (Cocos nucifera L.) coir dust. Arch. Appl. Sci. Res. 2012, 4, 809-819.

43. Al-Ghouti, M.A.; Da'ana, D.A. Guidelines for the use and interpretation of adsorption isotherm models: A review. J. Hazard. Mater. 2020, 393, 122383. [CrossRef]

44. Hu, Q.; Zhang, Z. Application of Dubinin-Radushkevich isotherm model at the solid/solution interface: A theoretical analysis. J. Mol. Liq. 2019, 277, 646-648. [CrossRef]

45. Moreno Marenco, A.R. Estudio de Diferentes Bioadsorbentes Como Posibles Retenedores de Fosfatos en Aguas; Universidad Nacional de Colombia: Bogotá, Colombia, 2013.

46. El-Peruano. Aprueban las Listas de Insumos Químicos, Productos y sus Subproductos o Derivados que son Objeto de Control, y Definen los Bienes Fiscalizados Considerados de Uso Doméstico y Artesanal, Conforme lo Establecido en los Artículos 5 y 16 del Decreto Legislativo $\mathrm{N}^{\circ}$ 1126. DECRETO SUPREMO No 268-2019-EF. 2019; pp. 13-16. Available online: https:/ / busquedas.elperuano.pe/normaslegales/aprueban-las-listas-de-insumos-quimicos-productos-y-sus-sub-decretosupremo-n-268-2019-ef-1799604-5/ (accessed on 15 June 2021).

47. Mosoarca, G.; Vancea, C.; Popa, S.; Gheju, M.; Boran, S. Syringa vulgaris leaves powder a novel low-cost adsorbent for methylene blue removal: Isotherms, kinetics, thermodynamic and optimization by Taguchi method. Sci. Rep. 2020, 10, 17676. [CrossRef] [PubMed]

48. Uddin, M.K.; Nasar, A. Walnut shell powder as a low-cost adsorbent for methylene blue dye: Isotherm, kinetics, thermodynamic, desorption and response surface methodology examinations. Sci. Rep. 2020, 10, 7983. [CrossRef] [PubMed]

49. Bhatnagar, A.; Sillanpää, M.; Witek-Krowiak, A. Agricultural waste peels as versatile biomass for water urification-A review. Chem. Eng. J. 2015, 270, 244-271. [CrossRef]

50. Kumar, P.S.; Korving, L.; van Loosdrecht, M.C.M.; Witkamp, G.-J. Adsorption as a technology to achieve ultra-low concentrations of phosphate: Research gaps and economic analysis. Water Res. X 2019, 4, 100029. [CrossRef]

51. De Gisi, S.; Lofrano, G.; Grassi, M.; Notarnicola, M. Characteristics and adsorption capacities of low-cost sorbents for wastewater treatment: A review. Sustain. Mater. Technol. 2016, 9, 10-40. [CrossRef]

52. Bansal, R.C.; Goyal, M. Activated Carbon Adsorption; CRC Press: Boca Raton, FL, USA, 2005.

53. Zheng, H.; Wang, Z.; Deng, X.; Zhao, J.; Luo, Y.; Novak, J.; Herbert, S.; Xing, B. Characteristics and nutrient values of biochars produced from giant reed at different temperatures. Bioresour. Technol. 2013, 130, 463-471. [CrossRef] 
54. Chen, B.; Chen, Z.; Lv, S. A novel magnetic biochar efficiently sorbs organic pollutants and phosphate. Bioresour. Technol. 2011, 102, 716-723. [CrossRef]

55. Karthikeyan, P.; Meenakshi, S. Fabrication of hybrid chitosan encapsulated magnetic-kaolin beads for adsorption of phosphate and nitrate ions from aqueous solutions. Int. J. Biol. Macromol. 2021, 168, 750-759. [CrossRef] [PubMed]

56. AWWA. B604-18 AWWA Standard Granular Activated Carbon; American Water Works Association: Denver, CO, USA, 2018.

57. Budianto, A.; Kusdarini, E.; Effendi, S.S.W.; Aziz, M. The production of activated carbon from Indonesian mangrove charcoal. IOP Conf. Ser. Mater. Sci. Eng. 2019, 462, 012006. [CrossRef]

58. Kumar, Y.; Yadav, D.N.; Ahmad, T.; Narsaiah, K. Recent trends in the use of natural antioxidants for meat and meat products. Compr. Rev. Food Sci. Food Saf. 2015, 14, 796-812. [CrossRef]

59. Johansson, L.; Gustafsson, J.P. Phosphate removal using blast furnace slags and opoka-mechanisms. Water Res. 2000, 34, 259-265. [CrossRef]

60. Hernández-Rodríguez, M.; Otero-Calvis, A.; Falcón-Hernández, J.; Yperman, Y. Características fisicoquímicas del carbón activado de conchas de coco modificado con $\mathrm{HNO}_{3}$. Rev. Cuba. Quim. 2017, 29, $26-38$.

61. Moreno-Piraján, J.C.; Navarrete, L.F.; Giraldo, L.; García, V. Adsorción de fenol y 3-cloro fenol sobre carbones activados mediante calorimetría de inmersión. Inf. Tecnol. 2007, 18,71-80. [CrossRef]

62. Valdés, H.; Zaror, C.A. Influencia de la composición química superficial del carbón activado en la adsorción de benzotiazoles. Rev. Chi. Ing. 2010, 18, 38-43. [CrossRef]

63. Jiménez Ramos, I.; Rondon, W.; Astudillo, L.R. Síntesis de carbón activado a partir de epicarpio de Attalea macrolepis y su aplicación en la remoción de $\mathrm{Pb}^{2+}$ en soluciones acuosas. Rev. Int. Contam. Ambient. 2017, 33, 303-316. [CrossRef]

64. Anee, T.K.; Meenakshi Sundaram, N.; Arivuoli, D.; Ramasamy, P.; Narayana Kalkura, S. Influence of an organic and an inorganic additive on the crystallization of dicalcium phosphate dihydrate. J. Cryst. Growth 2005, 285, 380-387. [CrossRef]

65. Wang, Z.; Xing, M.; Fang, W.; Wu, D. One-step synthesis of magnetite core/zirconia shell nanocomposite for high efficiency removal of phosphate from water. Appl. Surf. Sci. 2016, 366, 67-77. [CrossRef]

66. Trinh, V.T.; Nguyen, T.M.P.; Van, H.T.; Hoang, L.P.; Nguyen, T.V.; Ha, L.T.; Vu, X.H.; Pham, T.T.; Nguyen, T.N.; Quang, N.V.; et al. Phosphate adsorption by silver nanoparticles-loaded activated carbon derived from tea residue. Sci. Rep. 2020, 10, 3634. [CrossRef]

67. Chowdhury, S.; Mishra, R.; Saha, P.; Kushwaha, P. Adsorption thermodynamics, kinetics and isosteric heat of adsorption of malachite green onto chemically modified rice husk. Desalination 2011, 265, 159-168. [CrossRef]

68. Ramón de los Santos, C.; Barajas Fernández, J.; Pérez Hernández, G.; Díaz Flores, L.L. Adsorción de cobre (II) y cadmio (II) en suspensiones acuosas de CaCO3 biogénico nanoestructurado. Bol. Soc. Esp. Ceram. V 2019, 58, 2-13. [CrossRef]

69. Ahmad, M.; Akanji, M.A.; Usman, A.R.A.; Al-Farraj, A.S.F.; Tsang, Y.F.; Al-Wabel, M.I. Turning date palm waste into carbon nanodots and nano zerovalent iron composites for excellent removal of methylthioninium chloride from water. Sci. Rep. 2020, 10, 16125. [CrossRef]

70. Reátegui-Romero, W.; Cadenas-Vásquez, W.J.; King-Santos, M.E.; Zaldivar Alvarez, W.F.; Posadas, R.A.Y. Evaluation of Pb (II) adsorption from aqueous solutions using Brassica nigra as a biosorbent. Open Biotechnol. J. 2019, 13, 77-92. [CrossRef]

71. Inglezakis, V.J.; Stylianou, M.A.; Gkantzou, D.; Loizidou, M.D. Removal of $\mathrm{Pb}$ (II) from aqueous solutions by using clinoptilolite and bentonite as adsorbents. Desalination 2007, 210, 248-256. [CrossRef]

72. Sarı, A.; Tuzen, M.; Citak, M.; Soylak, M. Adsorption characteristics of $\mathrm{Cu}$ (II) and $\mathrm{Pb}$ (II) onto expanded perlite from aqueous solution. J. Hazard. Mater. 2007, 148, 387-394. [CrossRef] [PubMed]

73. Li, Y.; Jin, H.; Liu, W.; Su, H.; Lu, Y.; Li, J. Study on regeneration of waste powder activated carbon through pyrolysis and its adsorption capacity of phosphorus. Sci. Rep. 2018, 8, 778. [CrossRef]

74. Xiong, W.; Tong, J.; Yang, Z.; Zeng, G.; Zhou, Y.; Wang, D.; Song, P.; Xua, R.; Zhang, C.; Cheng, M. Adsorption of phosphate from aqueous solution using iron-zirconium modified activated carbon nanofiber: Performance and mechanism. J. Colloid Interface Sci. 2017, 493, 17-23. [CrossRef] [PubMed]

75. Nan, L.; Baoqing, S.; Wenzhong, T. Preparation of powder activated carbon by rice husks and its adsorption capacity to phosphorus. Chin. J. Environ. Eng. 2013, 7, 1024-1028.

76. Rashid, M.; Price, N.T.; Gracia Pinilla, M.A.; O'Shea, K.E. Effective removal of phosphate from aqueous solution using humic acid coated magnetite nanoparticles. Water Res. 2017, 123, 353-360. [CrossRef] [PubMed] 